\title{
Perbandingan konsumsi bahan bakar minyak hasil pirolisis plastik HDPE bercampur serabut kelapa terhadap premium
}

\author{
Diego Alfin Alfiando ${ }^{1)}$, Irwan Setyowidodo ${ }^{2)}$, Nuryosuwito ${ }^{3)}$ \\ 1), 2), 3) Program Studi Teknik Mesin, Univ. Nusantara PGRI Kediri \\ E-mail: ${ }^{2)}$ Irwansetyo@ unpkediri.ac.id, ${ }^{3)}$ Suwito.unpkediri@ gmailcom
}

\begin{abstract}
Abstrak
Salah satu alternative penanganan sampah plastik yang saat ini banyak diteliti dan dikembangkan adalah mengubah sampah plastik menjadi bahan bakara lternatif dan serabut kelapa telah di gunakan sebagai bahan bakar untuk menghasilkan energi mekanik dan panas. Kandungan silika $\left(\mathrm{S}_{-} \mathrm{iO}_{2}\right)$ pada abu serabut kelapa yang tinggi yang dapat di gunakan sebagai sumber alternatif. Tujuan penelitian ini adalah untuk memperoleh bahan bakar cair dari pirolisis sampah plastik, dengan nilai kalor dan mutu bahan bakar minyak yang baik. Metode yang digunakan adalah Plastik yang pada dasarnya terbuat dari minyak bumi akan dikembalikan lagi ke bentuk asalnya dengan cara menggunakan proses pirolisis. Pirolisis atau devolatilisasi adalah proses fraksinasi material oleh suhu. Dengan pengujian konsumsi bahan bakar didapat hasil nilai konsumsi plastik HDPE yang terkecil sebesar 4 ml mengunakan Rpm 2000 dengan selang waktu 2 menit sedangkan nilai premium yang terkecil sebesar $10 \mathrm{ml}$ dengan Rpm dan waktu yang sama kerena nilai oktan sebesar 97 yang hampir sama dengan nilai oktan Pertamax turbo.
\end{abstract}

Kata Kunci: Bahan bakar alternatif, HDPE, Pirolisis, Sampah plastik, serabut kelapa.

\begin{abstract}
One alternative to handling plastic waste that is currently being researched and developed is to convert plastic waste into alternative fuel and coconut fibers that have been used as fuel to produce mechanical energy and heat. Silica $\left(\mathrm{S}_{-} i \mathrm{O}_{2}\right)$ content in high coconut fiber ash which can be used as an alternative source. The purpose of this study was to obtain liquid fuels from pyrolysis of plastic waste, with good heating value and quality of fuel oil. The method used is plastic which is basically made from petroleum will be returned to its original form by using a pyrolysis process. Pyrolysis or devolatilization is the process of fractionating material by temperature. By testing fuel consumption, the smallest HDPE plastic consumption value is $4 \mathrm{ml}$ using Rpm 2000 with an interval of 2 minutes while the smallest premium value is $10 \mathrm{ml}$ with Rpm and the same time because the octane value is 97 which is almost the same as the octane value Pertamax turbo.
\end{abstract}

Keywords: alternative fuels, coconut fibers, HDPE, Plastic waste, pyrolysis. 


\section{PENDAHULUAN}

Plastik jenis bahan non-biodegradable yang sulit diuraikan oleh alam salah satu ide dalam pencarian sumber energi alternatif mengonversi sampah plastik menjadi hidrokarbon cair. Hidrokarbon cair merupakan senyawa kimia yang banyak di perlukan oleh banyak industri. Jenis kemasan plastik yang dikenal dengan poli etilene adalah polimer dari monomer etilen yang di buat dengan proses polimerisasi adisi dari gas etilen yang di peroleh dari hasil samping industri minyak dan batu bara. Plastik HDPE memiliki titik leleh $200^{\circ} \mathrm{C}-280^{\circ} \mathrm{C}$ dan dapat terdekomposisi pada suhu $495^{\circ} \mathrm{C}$. Sampel plastik HDPE yang telah dipirolisis menghasilkan char yang mengandung paraffins dan 1-olefins. Paraffins mengandung hidrokarbon rantai panjang yang biasanya terdapat pada bahan bakar. Paraffins berbentuk seperti lilin yang berwujud pada temperatur ruangan dan memiliki titik leleh $>370^{\circ} \mathrm{C}$. Padatan hasil HDPE apabila dilakukan pengolahan lanjutan dapat digunakan sebagai bahan bakar padat alternative [1]. Plastik HDPE (High Density Polyethylene) adalah salah satu jenis plastik yang ada di dunia saat ini, kalau dilihat secara visual jenis plastik HDPE bahan yang lebih kuat, keras, buram dan lebih tahan terhadap suhu tinggi. Biasa dipakai untuk botol susu yang berwarna putih susu, tupperware, galon air minum dan lain-lain.

Penelitian pirolisis menggunakan massa 500 gram menghasilkan gas 14,60\%; wax 69,91\%; dan char 15,49\%. Literatur menyebutkan pirolisis dengan bahan HDPE yang dilakukan pada suhu $500^{\circ} \mathrm{C}$ menghasilkan gas 0,9\%; wax 97,7\%; dan char $0,8 \%$ [2]. Konversi pirolisis massa plastik atau konversi volatile matter. Untuk menghitung konversi, massa plastik dalam reaktor (residu padat) diukur pada berbagai variasi waktu dan suhu. Nilai massa yang tervolatilisasi pada plastik tiap saat dan total massa yang bisa tervolatilisasi adalah pada plastik. Konversi volatil matter dalam plastik [3]. Serabut kelapa telah di gunakan sebagai bahan bakar untuk menghasilkan energi mekanik. Panas.kandungan silika ( $\mathrm{S} \__{-} \mathrm{O}_{2}$ ) pada abu serabut kelapa yang tinggi dapat digunakan sebagai sumber selika alternatif. Premium bahan bakar minyak jenis distilat berwarna kekuningan yang jernih. Kandungan (RON) pada premium 88. Premium di produksi kebanyakan dari komponen lokal menggunakan tambahan pewarna kandungan sulfur maksimal $0,15 \% \mathrm{~m} / \mathrm{m}$ atau setara dengan $1500 \mathrm{ppm}$. 
Faktor-faktor yang mempengaruhi sempurna atau tidaknya proses pembakaran, pertama kualitas bahan bakar,yaitu bahan bakar yang memiliki ketahanan terhadap detonasi yang baik kedua kondisi ruang bakar, ruang bakar harus bersih dari kerak-kerak yang menempel,ketiga homogenitas dan perbandingan campuran antara bahan bakar dengan udara,keempat sistem pengapian,yaitu suatu sistem pada motor bensinyang di gunakan untuk menghasilkan loncatan bunga api pada busi sehingga bahan bakar dan udara dapat terbakar didalam ruang bakar, kelima tekanan kompresi,yaitu tekanan gas maksimum saat akhir langkah kompresi.

Pirolisis adalah fraksinasi material oleh suhu. Proses pirolisis dimulai padatemperatur sekitar $230^{\circ} \mathrm{C}$. Ketika komponen yang tidak stabil secara termal, danvolatil matters pada sampah akan pecah dan menguap bersamaan dengankomponen lainnya, produk cair yang menguap mengandung tar dan polyaromatic hidrokarbon [4]. Pirolisis merupakan peruraian dengan bantuan panas tanpa adanya oksigen ataudengan jumlah oksigen yang terbatas. Biasanya terdapat tiga produk dalam prosespirolisis yaitu arang, gas, dan cairan. Pada proses pirolisis Faktor- Faktor yang mempengaruhi proses pirolisis adalah waktu, suhu, ukuran partikel, dan berat partikel [5].

Faktor-faktor tersebut dapat dijelaskan, sebagai berikut :

a. Waktu

Waktu berpengaruh pada produk yang akan dihasilkan karena, semakin lamawaktu pirolisis berlangsung, produk yang di hasilkan semakin naik.

b. Suhu

Suhu sangat berpengaruh terhadap produk yang di hasilkan karena semakintinggi nilai konstanta dekomposisi termal akibatnya laju pirolisis bertambahdan konversi naik. Pengaturan suhu dalam tangki pirolisis. Sehingga plastikdapat meleleh dengan cepat dan kemudian menguap sampai habis.

c. Ukuran Partikel

Ukuran partikel berpengaruh terhadap hasil. Semakin besar ukuran partikelluas permukaan per satuan berat semakin kecil,sehingga proses akan menjadi lambat. 


\section{d. Berat Partikel}

Semakin banyak bahan yang dimasukkan menyebabkan hasil bahan bakar cairdan arang meningkat

\section{METODE PENELITIAN}

Pendekatan penelitian kuantitatif adalah pendekatan ilmiah yang memandang suatu realitas itu dapat diklasifikasikan, fakta, konkrit, bersifat sebab akibat dimana data penelitiannya berupa angka-angka dan analisisnya menggunakan statistik. Pendekatan analisis kuantitatif terdiri atas perumusan masalah, menyusun model, mendapatkan data, mencari solusi, menguji solusi, menganalisis hasil, dan menginterprestasikan hasil. Untuk Pengujian hasil perbadingan konsumsi bahan bakar pada mesin motor pada jeda waktu dalam 2 menit untuk bahan bakar berkapasitas $200 \mathrm{ml}$ bahan bakar jenis Premium dan Plastik HDPE. Data Metode pengolahan peneliti ini adalah pemakaian konsumsi bahan bakar dengan di uji menggunakan mesin motor. Dimana mesin ini digunakan untuk mengetahui nilai konsumsi yang di hasilkan. Hasil nilai konsumsi ini yang akan analisa dengan ANOVA (Analysis Of Varians) sehingga akan mengetahui beberapa konsumsi bahan bakar yang dibandingkan.

\section{HASIL DAN PEMBAHASAN}

Instalasi peralatan pirolisis merupakan komponen penting untuk memperoleh hasil produk yang diinginkan. Model reaktor yang digunakan juga menentukan merata atau tidaknya pembakaran. Selain itu konstruksi kondensor yang dibuat miring juga mempengaruhi keluarnya cairan yang keluar dari piapa output. Untuk mengurangi kehilangan kalor yang berlebihan, tempat pembakaran dilapisi dengan tungku. Dan kemudian dilapisi dengan plat besi yang menutup seluruh bagian. Berikut merupakan gambar instalasi peralatan pirolisis. 


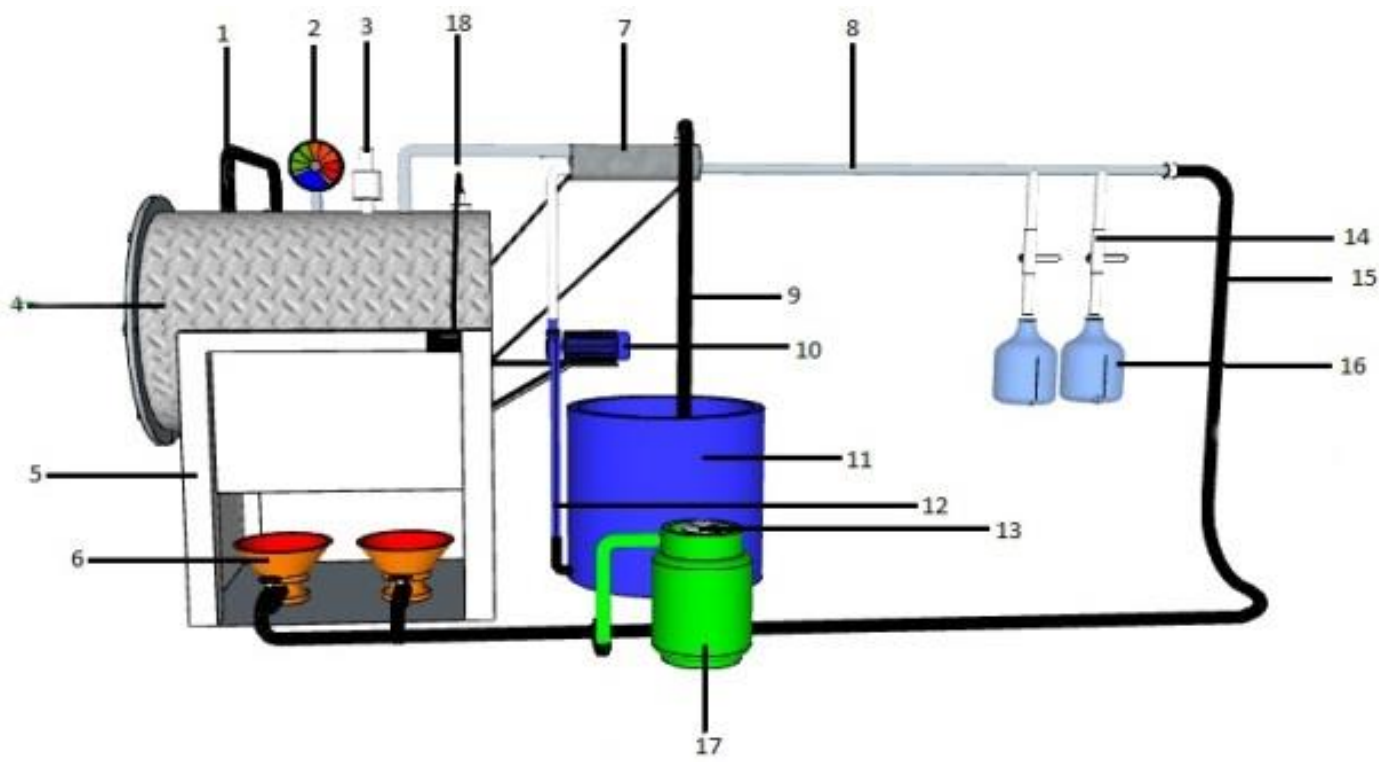

Gambar 1. Instalasi perlatan pengujian pirolisis

1. Nitrogen /N2

2. Manometer

3. Otomatis tekanan tinggi

4. Reactor

5. Pondasi

6. Kompor

7. Kondensor

8. Pipa

9. Pipa keluaran air konsensor
10. Pompa

11. Wadah air kondensor / bak

12. Pipa masukan air kondensor

13. Regulator

14. Valve

15. Selang lpg

16. Botol penampung hasil

17. Gas lpg

18. Termokopel

Serabut kelapa dipilih karena kelimpahannya yang banyak di Indonesia sebagai penghasil produk tanaman kelapa, di samping itu karena diantara biomassa yang lain, sabut kelapa termasuk yang mempunyai nilai kalori yang tergolong tinggi sehingga diharapkan dapat menaikkan nilai kalor briket yang dihasilkan. 




Gambar 2. Serabut kelapa

Data pengujian percobaan sebanyak 10 kali dengan jenis bahan bakar plastik HDPE dan Serabut kealapa dengan Premium dengan kecepatan Rpm 2000 dan waktu selama 2 menit. Data hasil pengujian berdasarkan percobaan sebanyak 10 kali dengan jenis bahan bakar Hasil produk pirolisis dan premium dengan kecepatan Rpm 2000 dan waktu selama 2 menit, maka di peroleh hasil sebanyak 10 kali pengujian yang selanjutnya akan di peroleh nilai rata-rata konsumsi bahan bakar Premium dan bahan bakar hasil pirolisis.

Tabel 1. Hasil pengujian

\begin{tabular}{|c|c|c|c|}
\hline No & Bahan bakar & Konsumsi (ml) & Rata - rata \\
\hline \multirow{8}{*}{1} & \multirow{8}{*}{ Plastik HDPE dan serabut kelapa } & 8 & \multirow{8}{*}{6} \\
\hline & & 6 & \\
\hline & & 6 & \\
\hline & & 4 & \\
\hline & & 6 & \\
\hline & & 8 & \\
\hline & & 6 & \\
\hline & & 4 & \\
\hline \multirow{5}{*}{2} & \multirow{5}{*}{ Premium } & 14 & \multirow{5}{*}{14} \\
\hline & & 16 & \\
\hline & & 12 & \\
\hline & & 20 & \\
\hline & & 10 & \\
\hline
\end{tabular}

Perbandingan konsumsi bahan bakar minyak hasil pirolisis plastik HDPE bercampur serabut kelapa terhadap premium (Diego Alfin Alfiando, Irwan Setyowidodo, Nuryosuwito) 


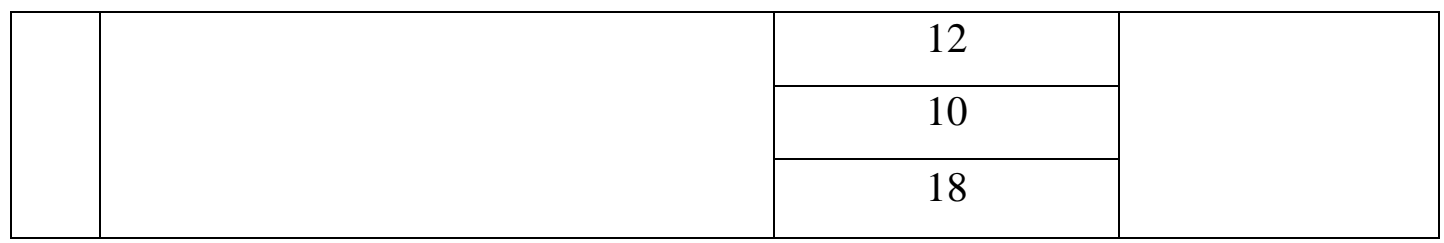

Maka dapat di simpulkan bahwa pada umumnya hasil pengujian pada sepeda motor dengan penggunaan bahan bakar yang berbeda premium dengan bahan bakar jenis plastik HDPE+serabut kelapa menunjukkan bahwa samakin tinggi kecepatan semakin boros konsumsi dan semakin lama waktu tempuhnya terjadi pada tiap Rpm sepeda motor akan semakin boros juga konsumsi yang digunakan.

Uji kenormalan residual dilakukan dengan menggunakan uji Anderson-Darling yang terdapat pada program minitab 16. Uji ini dilakukan untuk mengetahui apakah data variabel berdistribusi normal atau tidak. Penelitian menggunakan taraf signifikan kesalahan sebesar $\alpha=5 \%(0.05)$ dengan kata lain tingkat keyakinan sebesar $95 \%$.



Gambar 3. Plot Uji Distribusi Normal Pada Respon perbandingan konsumsi plastik HDPE dan serabut kelapa dengan premium

Gambar diatas menunjukkan bahwa dengan menggunakan uji AndersonDarling Diperoleh p-Value pada pengujian konsumsi sebesar 0,201. Jadi hasil uji distribusi normal dapat disimpulkan pengujian konsumsi bahan bakar p-Value lebih dari $\alpha=0,05$ maka merupakan residual berdistribusi normal.

kemudian uji identik untuk mengetahui apakah data penelitian yang dihasilkan identik atau tidak. Bila sebaran data pada output uji ini tersebar secara acak dan 
tidak membentuk pola tertentu disekitar harga nol maka data memenuhi asumsi identik. Namun bila output uji ini tersebar secara tidak acak dan membentuk pola tertentu disekitar harga nol maka data tidak memenuhi asumsi identik yang diperlukan.

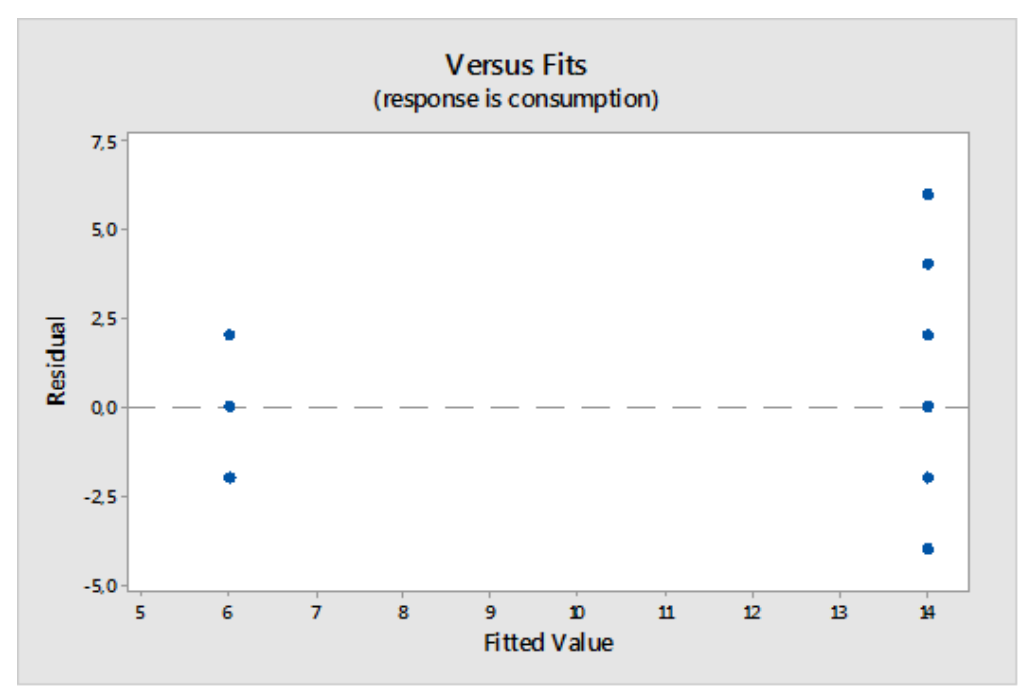

Gambar 4. Plot Residual Pada Respon berbandingan konsumsi plastik HDPE dan serabut kelapa dengan premium Versus Fitted Values

Gambar di atas menunjukkan bahwa pengujian nilai oktan memiliki residual tersebar secara acak disekitar harga minus dan tidak membentuk pola tertentu. Dengan demikian asumsi residual identik terpenuhi.

Pengujian independen pada penelitian ini dilakukan dengan menggunakan auto correlation function (ACF) yang terdapat pada program minitab 16. Pengujian ini untuk mengetahui apakah terdapat nilai ACF yang keluar dari batas interval atau tidak. Bila tidak terdapat nilai yang melebihi batas interval maka data penelitian ini memenuhi asumsi independen, namun bila terdapat data penelitian yang melebihi batas interval maka terdapat hasil pengukuran yang terpengaruh oleh hasil pengukuran lainnya. 


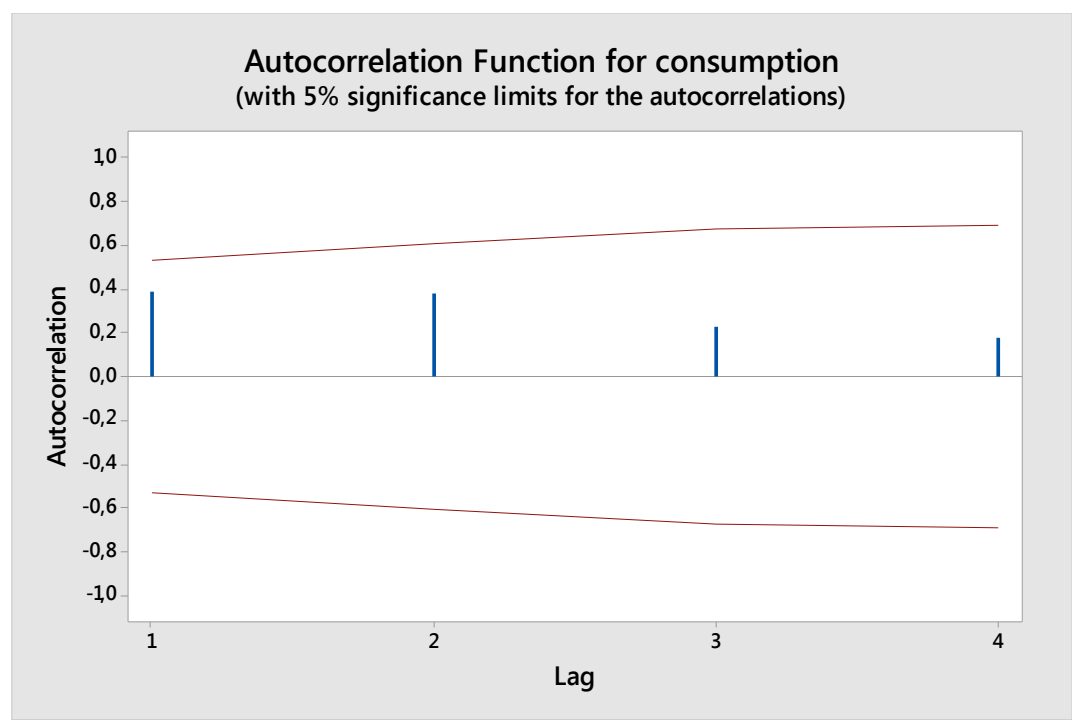

Gambar 5. Plot ACF Pada Respon nilai berbandingan konsumsi plastik HDPE dan serabut kelapa dengan premium.

Berdasarkan plot ACF yang ditunjukkan pada gambar 4.6, tidak ada nilai ACF pada lag yang keluar dari batas interval. Hal ini membuktikan bahwa tidak ada kolerasi antar residual artinya bersifat independen.

hasil analisis data menggunakan analysis of varians (ANOVA) dengan distribusi F. Hipotesis awal (H0) akan ditolak apabila nilai Fhitung melebihi nilai Ftabel. Untuk Fhitung didapatkan dari hasil analisa program minitab dan untuk Ftabel dari hasil $\mathrm{F} \alpha$, a-1, N-a, dimana "a" adalah banyak replikasi ditiap level faktor dan $\mathrm{N}$ adalah banyaknya seluruh pengamatan. Untuk mendapatkan nilai Ftabel dapat kita lihat tabel Prescentage Point of the Distribution (continued) pada halaman lampiran. Penarikan hasil untuk nilai alkohol, nilai kalor daan temperatur nyala api berdasarkan tabel distribusi untuk $F(0.05 ; 01,14)$ sebesar 3,50. Selain menggunakan nilai $\mathrm{F}$, kita bisa juga menggunakan $\mathrm{P}$-Value untuk menguji hipotesis awal (H0) akan ditolak bila P-Value kurang dari nilai taraf signifikan $\alpha$, dalam penelitian $\alpha$ (signifikan) bernilai $0.05=5 \%$. 
Tabel 2. Perbandingan konsumsi bahan bakar plastik HDPE dan serabut kelapa dengan premium

One-way ANOVA: konsumsi versus bahan bakar

\begin{tabular}{lrrrrr} 
Source & DF & Adj SS & Adj MS & F-Value & P-Value \\
\hline Fuel & 1 & 256,0 & 256,000 & 32,00 & 0,000 \\
Error & 14 & 112,0 & 8,000 & & \\
Total & 15 & 368,0 & & &
\end{tabular}

Jika dilihat dari nilai $\mathrm{F}_{\text {hitung }}$ pada tabel 4.3 analisa variasi variabel proses terhadap perbandingan konsumsi antara plastik HDPE dan serabut kelapa dengan premium untuk proses distilasi sebesar 32,00. Untuk P-Value yang dihasilkan sesuai analisa ini untuk setiap variabel memiliki nilai yang sangat signifikan. Pada tabel 4.3 analisa variasi variabel proses terhadap perbandingan konsumsi plastik HDPE dan serabut kelapa dengan premium. Variabel bebas hasil proses pirolisis memiliki $P$-Value sebesar 0.000. dilihat dari reratanya, premium memberikan hasil yang lebih baik dari hasil pirolisis plastik HDPE yang dicampur dengan serabut kelapa.

Dari hasil pengujian laboratorium, juga diketahui ukuran densitas, viskositas, dan flash point.

Tabel 3. Hasil uji lab

\begin{tabular}{|c|c|c|c|c|c|}
\hline \multirow{2}{*}{ Propertis } & \multirow{2}{*}{ Unit } & \multicolumn{3}{|c|}{ HDPE + Serabut } & \multirow{2}{*}{ Methode*) } \\
\cline { 3 - 6 } & Simplo & Duplo & Triplo & Picnometer \\
\hline Density & $\mathrm{gr} / \mathrm{cm}^{3}$ & 0,765890 & 0,765980 & 0,765495 & Piscometer \\
\hline $\begin{array}{c}\text { Kinematic } \\
\text { Viscosity }\end{array}$ & $\mathrm{Mm}^{2} / \mathrm{s}$ & 69,353152 & 69,384583 & 69,408347 & $\begin{array}{c}\text { Viscom } \\
\text { Ostwald }\end{array}$ \\
\hline Flash point & ${ }^{0} \mathrm{C}$ & 11 & 13 & 16 & $\begin{array}{c}\text { Closed } \\
\text { Cup }\end{array}$ \\
\hline
\end{tabular}

Dari grafik di atas dapat di gambarkan bahwa nilai density dari tiga replikasi menunjukkan bahwa semuanya hampir sama, dan nilai kinematic viscosity menunjukkan nilai yang hampir sama, sedangkan pada nilai flash point menunjukkan nilai yang berbeda nilai tertinggi sebesar 16 dan nilai terendah sebesar 11. 


\section{KESIMPULAN}

Berdasarkan latar belakang diatas, rumusan masalah yang diambil yaitu, bagaimana pengaruh perbandingan pemakaian konsumsi bahan bakar cair jenis plastik HDPE \& Serabut kelapa hasil produk pirolisis dengan bahan bakar premium terhadap kinerja mesin motor, maka hasil produk pirolisis mempunyai konsumsi bahan bakar hasil pirolisis lebih irit sedangkan premium lebih boros. Dengan penelitian ini memfariasi bahan bakar untuk mengetahui perbandingan konsumsi bahan bakar cair yang dihasilkan dari proses pirolisis jeneis plastik HDPE dan serabut kelapa dengan premium.

\section{DAFTAR PUSTAKA}

[1] Marpaung, R. R., Pengaruh Penambahan Sabut Kelapa Pada Campuran Beton Terhadap Kuat Tekan dan Sebagai Peredam Suara. Jurnal Teknik Sipil USU, 3(1)., 2014.

[2] Rachmawati, Qonita dan Herumurti, Welly, Pengolahan Sampah Secara Pirolisis Dengan Variasi Rasio Komposisi Sampah Dan Jenis Plastik, Jurnal Teknik ITS Vol. 4, No. 1, (2015) ISSN 2337-3539 (2301-9271 Printed). http://ejurnal.its.ac.id/index.php/teknik/article/view/8848, 2015.

[3] Ramadhan, A., \& Ali, M., Pengolahan Sampah Plastik Menjadi Minyak Menggunakan Proses Pirolisis, Jurnal Ilmiah Teknik Lingkungan. Vol. 4 No. 1., (http://jom.unri.ac.id/index.php/JOMFTEKNIK/article/viewFile/8044/7716). Diunduh 15 desember 2017, 2013.

[4] Ramadhan, A., \& Ali, M., Pengolahan Sampah Plastik Menjadi Minyak Menggunakan Proses Pirolisis, Jurnal Ilmiah Teknik Lingkungan. Vol. 4 No. 1., (http://jom.unri.ac.id/index.php/JOMFTEKNIK/article/viewFile/8044/7716). Diunduh 15 desember 2017, 2013.

[5] Silia, Frist dan Maulina, Seri. Pengaruh Suhu, Waktu, Dan Kadar Air Pada Pirolisis Pelepah Kelapa Sawit. Jurnal Teknik Kimia USU, Vol. 6, No. 2 (Juni 2017). https://jurnal.usu.ac.id/index.php/jtk/article/download/17861/7610, 2017. 